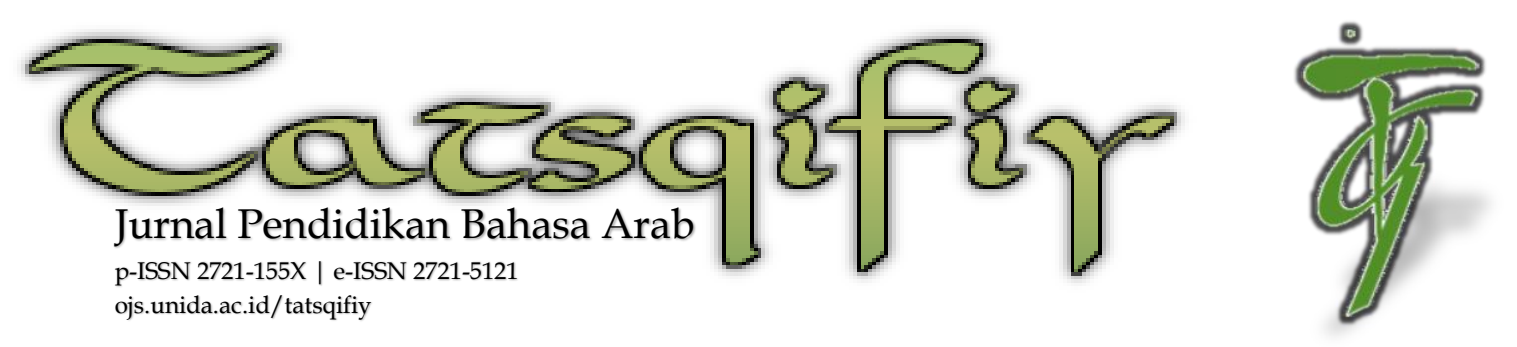

\title{
Persepsi Mahasiswa dalam Pemilihan Prodi Bahasa Arab
}

\author{
Yunita $^{1}$ \\ 1Program Studi Pendidikan Bahasa Arab, Fakultas Keguruan dan Ilmu Pendidikan \\ Universitas Djuanda Bogor; Jl. Tol Ciawi No. 1 Kotak Pos 35 Ciawi Bogor 16720
}

Volume 1 Nomor 2

Juli 2020: 113-125

DOI: $10.30997 /$ tjpba.v1i2.2796

Article History

Submission: 01-06-2020

Revised: 19-06-2020

Accepted: 02-07-2020

Published: 10-07-2020

Kata Kunci: persepsi, bahasa Arab

Keywords:

perception, Arabc learning

Korespondensi:

(Yunita)

(Telp. 089526841236)

(nitayunita088@gmail.com)

\begin{abstract}
Abstrak: Bahasa Arab merupakan bahasa asing yang belakangan ini banyak ditekuni oleh masyarakat untuk dipelajari dan ditelaah. Salah satunya Universitas Djuanda Bogor yang menerapkan adanya pembelajaran program studi (prodi) bahasa Arab. Adanya prodi bahasa Arab di Universitas Djuanda Bogor. Para mahasiswa tersebut, memliki persepsi masing-masing terhadap pemilihan prodi bahasa Arab. Tujuan penelitian ini untuk mengetahui persepsi pemilihan prodi bahasa Arab. Penelitian ini menggunakan pendekatan kualitatif dengan metode studi naratif. Data yang dikumpulkan menggunakan instrumen penelitian berupa wawancara dan kertas tes. Melalui penelitian ini diungkap bahwa mahasiswa menunjukkan persepsi yang berbeda dalam pemilihan prodi bahasa Arab. Persepsi mahasiswa terhadap pemilihan prodi bahasa Arab cukup positif disertai dengan minat dan kemampuan dalam pembelajaran bahasa Arab secara aktif.

Student Perceptions in the Selection of Arabic
Language Study Programs
Abstract: Arabic is a foreign language that lately is occu-
pied by many people to be studied and examined. One of
them is Djuanda University Bogor which is implementing
Arabic language study program. The students, each have
their perception of the selection of Arabic study programs.
The purpose of this research data is to determine the per-
ception of the choice of Arabic study program. This research
uses a qualitative approach with a narrative study method.
Data collected using research instruments such as inter-
views and test papers. Through this research it was revealed
different perception in the selection of Arabic. Student's per-
ception of language selection interest in learning Arabic is
quite positive accompanied by interest an ability in active
Arabic learning.
\end{abstract}


Persepsi Mahasiswa dalam Pemilihan Prodi Bahasa Arab

\section{PENDAHULUAN}

Bahasa Arab adalah salah satu bahasa internasional yang selalu berkembang dan sampai kepada kita saat ini melalui proses transformasi. Di samping itu, begitu komprehensif dan variatif dalam perspektif konteksnya, bahkan sangat sinergis ditinjau dari sektor makna, karena makna merupakan kajian /dhamir/ manusia yang terintegrasi, kendati setiap bangsa mengekspresikannya dengan konteks yang berbeda.

Mahasiswa dalam pemilihan prodi bahasa Arab, pada umum nya masih banyak yang kurang percaya diri dalam memilih prodi bahasa Arab. Disebabkan karena, mereka adalah lulusan dari Sekolah Menengah Atas (SMA) dan Sekolah Menengah Kejurusan (SMK). Sehingga, tidak sedikit yang dari mereka tidak mempunyai basic dalam pembelajaran tersebut. Sementara, yang lulusan dari pesantren sebaliknya mereka sangat percaya diri untuk masuk ke prodi bahasa Arab. Karena, lulusan dari pesantren biasanya sudah diajarkan pembelajaran bahasa Arab dalam kehidupan sehari-harinya. Berdasarkan uraian di atas, bahwa permasalahannya yaitu mahasiswa kesulitan dalam belajar bahasa
Arab. Sebab, mahasiswa tidak memiliki basic dalam bidang bahasa Arab. Oleh karena itu, tidak sedikit dari mereka dalam memilih prodi bahasa Arab masih kesulitan dalam mempelajari bahasa Arab. Akan tetapi, mereka selalu berusaha bertanya kepada teman-teman nya yang sudah berpengalaman dalam berbicara bahasa Arab.

Maka, ketika mahasiswa belajar bahasa Arab mereka harus aktif dalam berdiskusi, atau tanya jawab. Alasannya, karena orang yang sering bertanya akan cepat mahir dalam berbicara bahasa Arab. Menurut Soegeng A.Y (2012) pembelajaran aktif adalah kegiatan-kegiatan pembelajaran yang melibatkan para pelajar dalam melakukan suatu hal dan memikirkan apa yang sedang mereka lakukan. Pembelajaran aktif itu diturunkan dari dua asumsi dasar yaitu: 1) Bahwa belajar pada dasarnya adalah proses yang aktif, 2) Bahwa orang yang berbeda, belajar dalam cara yang berbeda pula.

Menurut Bonwell (1995), pembelajaran aktif memiliki karakteristik yaitu: 1) Penekanan proses pembelajaran bukan pada penyampaian informasi oleh pengajar melainkan pada pengembang- 
an keterampilan pemikiran analitis terhadap topik atau permasalahan yang dibahas, 2) Siswa atau mahasiswa tidak hanya mendengarkan kuliah secara pasif tetapi mengerjakan sesuatu yang berkaitan dengan materi pembelajaran/kuliah, 3) Penekanan pada eksplorasi nilai-nilai dan sikap-sikap berkenaan dengan materi pembelajaran/kuliah, 4) Siswa/mahasiswa lebih banyak dituntut untuk berpikir kritis, menganalisa dan melakukan evaluasi, 5) Umpan balik yang lebih cepat akan terjadi pada proses pembelajaran.

Berdasarkan uraian di atas, penulis berpendapat pembelajaran aktif adalah segala bentuk pembelajaran yang memungkinkan mahasiswa berperan secara aktif dalam proses pembelajaran itu sendiri baik dalam bentuk interaksi antar mahasiswa maupun mahasiswa dengan pengajar/dosen dalam proses pembelajaran tersebut.

Thomas (1972) mengemukakan bahwa setelah 10 kuliah, siswa/mahasiswa cenderung akan kehilangan konsentrasinya untuk mendengar kuliah yang diberikan oleh pengajar secara pasif. Hal ini tentu saja akan makin membuat pembelajaran tidak efektif jika kuliah terus dilanjutkan tanpa upaya-upaya untuk memperbaikinya. Dengan menggunakan cara-cara pembelajaran aktif hal tersebut dapat dihindari.

Pemindahan peran pada siswa/ mahasiswa untuk aktif belajar dapat mengurangi kebosanan ini bahkan bisa menimbulkan minat belajar siswa/ mahasiswa. Pada akhirnya hal ini akan membuat proses pembelajaran mencapai learning outcomes yang diinginkan.

Menurut Alkusairy (1998) pula mendapati bahwa masalah yang kerap dihadapi oleh pelajar ialah malu dan takut untuk bertutur dalam bahasa arab terutama sekali pelajar di Malaysia. Mereka merasa rendah diri dan takut untuk membuat kesilapan. Dalam kajian ini, sikap bahasa merujuk kepada sikap pelajar UiTM terhadap pembelajaran kemahiran lisan bahasa arab sama ada sikap terhadap bahasa ataupun aspek pengajaran guru. Ia melibatkan tiga aspek yaitu: 1) kognitif, 2) afektif, dan 3) konatif pelajar. Penelitian sebelumnya mengungkapkan pada dasarnya beberapa mahasiswa yang masuk ke prodi bahasa Arab yaitu: 1) Adanya minat, dan 2) Adanya motivasi dan saran dari kedua orang tuanya. 
Persepsi Mahasiswa dalam Pemilihan Prodi Bahasa Arab

Menurut Crow \& Alice (1984: 22) ada beberapa faktor yang mempengaruhi minat yaitu: 1) rangsangan yang datang dari lingkungan atau ruang lingkup yang sesuai dengan keinginan atau kebutuhan seseorang akan mudah minat menimbulkan minat. Misalnya kecenderungan terhadap belajar, hal ini se-seorang akan mempunyai hasrat ingin tahu terhadap ilmu pengetahuan, 2) minat seseorang terhadap obyek atau sesuatu hal.

Di samping itu, dipengaruhi oleh faktor dari dalam diri manusia dan oleh motif sosial, misal seseorang berminat pada prestasi tinggi agar dapat status sosial yang tinggi pula, dan 3) Faktor perasaan dan emosi ini mempunyai pengaruh. Akan tetapi, setelah mereka masuk ke prodi bahasa Arab mereka berpendapat bahwa belajar bahasa arab adalah pembelajaran yang terhadap obyek.

Penulis menyimpulkan bahwa, minat merupakan ketertarikan akan sesuatu objek yang berasal dari hati, bukan karena paksaan dari orang lain. Hal tersebut menunjukkan bahwa, minat yang dimiliki seseorang merupakan hasil dari proses pemikiran, emosi serta pembela- jaran sehingga menimbulkan suatu keinginan untuk mendalami objek atau suatu kegiatan tertentu. Oleh karena itu, minat pada masing-masing orang bisa berbeda meskipun berada dalam lingkungan yang sama.

Dalam pemilihan prodi bahasa Arab, mahasiswa tentunya tidak hanya sekedar minat saja. Akan tetapi, mereka mempunyai tujuan tertentu yaitu untuk bisa berbicara bahasa Arab yang baik, dan benar serta adanya motivasi yang membuat mereka yakin untuk masuk ke prodi bahasa Arab.

Menurut Winardi (2001: 2) motivasi merupakan hasil sejumlah proses, yang bersifat internal atau eksternal bagi seseorang individu, yang menyebabkan timbulnya sikap antusiasme dan persisten dalam melaksanakan kegiatan-kegiatan tertentu.

Menurut Imam Musbikin (2012) ada tiga (3) fungsi motivasi, yaitu: 1) motivasi sebagai pendorong buatan, pada mulanya anak didik tidak ada hasrat untuk belajar. Tetapi, karena ada sesuatu yang dicari munculah minatnya untuk belajar. 
Sesuatu yang tidak diketahui itu akhirnya mendorong anak didik untuk belajar dalam rangka mencari tahu. Jadi, motivasi berfungsi sebagai pendorong mempengaruhi sifat yang seharusnya anak didik ambil dalam rangka belajar. 2) Motivasi sebagai penggerak buatan. Dorongan psikologis yang melahirkan sikap terhadap anak didik itu merupakan suatu kekuatan yang tak terbendung, yang kemudian terjelas dalam bentuk gerakan psikofisik. Dalam hal ini anak didik sudah melakukan aktivitas belajar dengan segenap raga dan jiwa.

Sikap berada dalam kepastian perbuatan, sedangkan akal pikiran mencoba membedah nilai yang terpatri dalam wacana, prinsip, dalil, dan hukum, sehingga betul isi yang dikandung. 3) Motivasi sebagai pengarah perbuatan. Anak didik yang mempunyai motivasi dapat menyeleksi mana perbuatan yang harus dilakukan dan mana perbuatan yang mesti diabaikan. Seseorang anak didik yang ingin mendapatkan sesuatu dari sesuatu mata pelajaran tertentu, tidak mungkin dipaksakan untuk mempelajari mata pelajaran di mana tersimpan sesuatu yang dicari itu. Sesuatu yang ingin dicari anak didik merupakan tujuan belajar yang akan dicapainya.
Tujuan belajar tersebut merupakan pengarah yang memberikan motivasi kepada anak didik dalam belajar.

Berdasarkan paparan diatas, penelitian ini mengungkapkan bahwa persepsi mahasiswa berbeda-beda dalam memilih jurusan.

\section{METODE}

Metode penelitian tersebut, dilaksanakan di Universitas Djuanda Bogor, Jl. Tol Ciawi Bogor No.1 Kontak Pos 35 Ciawi Bogor 16720.

Penelitian ini menggunakan pendekatan kualitatif dengan metode studi naratif, karena yang ingin diketahui adalah persepsi mahasiswa dalam pemilihan prodi bahasa arab.

Adapun subjek penelitian ini, adalah mahasiswa/mahasiswi Universitas Djuanda Bogor yaitu mahasiswa kelas pagi dan sore semester II, dan TU (Tata Usaha).

Teknik pengumpulan data ini, dilakukan untuk mencari dan mengumpulkan data dari mahasiswa kelas pagi dan sore semester II dan TU (Tata Usaha). Data yang dikumpulkan menggunakan instrumen penelitian berupa wawancara dan kertas tes. 
Persepsi Mahasiswa dalam Pemilihan Prodi Bahasa Arab

\section{HASIL DAN PEMBAHASAN}

Hasil dari penelitian ini, adalah berupa persepsi mahasiswa dalam pemilihan prodi bahasa Arab, di mana mahasiswa menyukai pembelajaran bahasa Arab dikarenakan mereka memang mempunyai skill dan keterampilan dalam pembelajaran tersebut.

Menurut Dunette (1976) mendefinisikan skill sebagai kapasitas yang membutuhkan untuk melaksanakan beberapa tugas yang merupakan pencapaian dari hasil training pengalaman yang di dapat. Sedangkan menurut Nadler (1986: 73) skill merupakan kegiatan yang memerlukan latihan atau dapat diartikan sebagai pembelajaran awal untuk mengembangkan potensi yang ada dalam diri seseorang. Selain itu, keterampilan sangat penting untuk menunjang hasil belajar.

\section{Hakikat Persepsi}

Menurut Mulyana (2005: 167-168), persepsi merupakan proses internal yang memungkinkan kita memilih, mengorganisasikan, dan menafsirkan rangsangan dari lingkungan kita, dan proses tersebut yang mempengaruhi kita.

Menurut Walgito (2004: 124), persepsi merupakan suatu proses yang di- dahului oleh penginderaan. Penginderaan disini, merupakan suatu proses diterima dari stimulus oleh individu melalui alat penerimanya. Namun, proses tersebut tidak berhenti disitu saja, pada umumnya stimulus tersebut diteruskan oleh syaraf ke otak, sebagai pusat susunan syaraf, dan proses selanjutnya merupakan proses persepsi.

Robbins (2004: 164-167) mengemukakan bahwa proses terbentuknya persepsi berasal dari beberapa faktor eksternal dan internal. Faktor eksternal terdiri dari: 1) Ukuran, sesuatu yang besar maka akan lebih mudah menarik perhatian, 2) Kontras, sesuatu keadaan yang berlatar belakang kontras biasanya sangat menonjol, 3) Intensitas kuatnya suatu rangsangan, contohnya suara keras di dalam ruangan yang sepi, 4) Gerakan, perhatian seseorang akan lebih tertarik kepada obyek yang bergerak untuk dilihat daripada obyek sama tapi diam, 5) Sesuatu yang baru, obyek baru yang berada di lingkungan yang dikenal akan lebih menarik perhatian.

Sedangkan faktor-faktor internal yang mempengaruhi terbentuknya persepsi sebagai berikut: 1) Faktor fisiologis, seseorang yang distimulus oleh 
apa yang terjadi di luar dirinya melalui penginderaan seperti mata, kulit, lidah, telinga, dan hidung tidak semua memiliki kekuatan penginderaan yang sama. 2) Faktor psikologis, meliputi motivasi dan pengalaman belajar masa lalu.

Berdasarkan paparan diatas, penelitian ini mengungkapkan sejauh mana persepsi mahasiswa dalam memilih prodi bahasa Arab, yaitu bahwa mahasiswa sangat senang dalam mempelajari bahasa Arab, serta mereka mampu mengikuti pembelajaran secara aktif. Mahasiswa yang masuk prodi bahasa Arab tentunya dapat melatih kemampuannya dalam berbicara bahasa Arab yang baik dan benar.

\section{Hakikat Bahasa Arab}

Thoimah (1994: 26) mengemukakan bahwa bahasa adalah gabungan dari simbol bunyi berdasarkan aturan yang telah ditentukan, di mana orang-orang yang mempunyai kebudayaan tertentu untuk mengetahui maknanya dan bertujuan untuk komunikasi antara satu orang dengan yang lainnya.

Secara umum, dalam konteks pembelajaran bahasa Arab, pengajaran bahasa Arab bertujuan mengembangkan keterampilan berbahasa asing para pembelajar, dalam hal ini mahasiswa, secara lisan maupun tulisan. Dengan keterampilan lisan, mahasiswa diharapkan menguasai sejumlah kosa kata dan struktur kalimat dan dengannya dapat berbicara secara aktif dengan keterampilan tertulis mahasiswa diharapkan mampu membaca, memahami, dan berdiskusi tentang teks-teks ataupun wacana berbahasa arab, terutama yang berkaitan erat dengan agama Islam.

Dari uraian diatas, dapat disimpulkan bahwa bahasa merupakan lambang bunyi yang bersifar arbiter, yang dapat dipakai oleh sekelompok masyarakat untuk mendapatkan informasi. Dengan adanya bahasa masyarakat dapat berkomunikasi sesuai dengan bahasa yang dimilikinya dan segala permasalahan dapat dipecahkan dengan adanya alat komunikasi atau bahasa.

Oleh karena itu, mahasiswa perlu adanya keterampilan untuk meningkatkan kemampuannya dalam berbicara bahasa Arab. Menurut Gordon (1994: 55) keterampilan merupakan kemampu-an untuk melakukan suatu pekerjaan secara mudah dan cepat, 
Persepsi Mahasiswa dalam Pemilihan Prodi Bahasa Arab

pengertian ini biasanya cenderung pada aktivitas psi-komotor.

Menurut Al-Ghalayin (2005: 5), bahasa Arab adalah kalimat-kalimat yang dipergunakan oleh orang arab untuk mengungkapkan tujuan-tujuan (pikiran dan perasaan) mereka.

Bahasa arab adalah sebuah bahasa yang terbesar dari segi jumlah penutur dalam keluarga bahasa semitik. Bahasa Arab adalah kalimat yang dipergunakan oleh orang Arab untuk menyampaikan maksud dan tujuan mereka. Yang berbentuk huruf hijaiyah yang dipergunakan oleh orang Arab dalam berkomunikasi dan berinteraksi sosial baik secara lisan maupun tulisan. Setiap Bahasa adalah komunikatif bagi para penuturnya.

Dilihat dari sudut pandang ini, tidak ada Bahasa yang lebih unggul daripada bahasa yang lain. Maksudnya bahwa bahasa memiliki kesamarataan dalam statusnya, yaitu sebagai alat komunikasi. Setiap komunikasi tentu saja menuntut kesepahaman di antara pelaku komunikasi.

Adapun ruang lingkup pembelajaran bahasa Arab secara umum men- cakup: 1) Unsur-unsur kebahasaan, yaitu tata bahasa /qawa'id/, kosakata / mufradat/, pelafalan, dan ejaan /aswat/, 2) keterampilan berbahasa, yaitu menyimak /istima'/, berbicara /muhadasah/, membaca /qiraah/, dan menulis /kitabah/, dan 3) aspek budaya yang terkandung dalam teks lisan dan tulisan.

Sementara itu, kebanyakan yang dari mahasiswa adalah anak lulusan dari pesantren. Sehingga, dapat dikatan bahwa mereka adalah mahasiswa yang mempunyai kemauan untuk masuk ke prodi bahasa Arab. Selain itu, dari beberapa mahasiswa yang bukan dari lulusan pesantren, faktornya adalah adanya dorongan dari orang lain serta dorongan dari orang tuanya yang memberikan motivasi kepadanya bahwa prodi bahasa Arab adalah pembelajaran yang menarik dan menyenangkan. Sehingga, mereka bersedia untuk masuk ke jurusan prodi bahasa Arab.

Namun, beberapa mahasiswa ada yang kesulitan dalam belajar bahasa Arab. Tapi, mereka sangat bersemangat dan bersungguh-sungguh dalam mempelajarinya. Karena, di dalam pembelajaran tersebut mereka mendapatkan pembelajaran yang berbeda. Misalnya, 
dalam belajar bahasa Arab ada yang namanya pembelajaran nahwu. Nahwu merupakan kaidah-kaidah tata bahasa arab yang /sukun/atau /kasroh/ mendasar.

Maftuh (1999:3) mengemukakan nahwu adalah pengatur atau penentu dari suatu kata. Maksudnya dialah yang memberi /harakat/ pada setiap akhir kata, apakah di /harakatin/, /fathah/, / dhommah/. Dahlan (2012: 3) mengemukakan nahwu adalah ilmu tentang kaidah-kaidah, untuk mengetahui hukum kata bahasa arab ketika, tersusun dalam kalimat dari segi / i'rab/dan/mabni/nya, termasuk didalamnya sebab-sebab pembatalan hukum dan penghapusan kata ganti.

Sedangkan Mustafa (2009: 8) mengemukakan nahwu adalah ilmu tentang, kaidah-kaidah yang dengannya diketahui keadaan kata bahasa arab, dari segi /i'rob/, dan /mabni/nya. Artinya, dari segi keadaan susunannya kita bisa mengetahui akhir kata tersebut dalam keadaan /rafa'/, /nashab/, /jar/, /jazm/, ketika berada dalam suatu kalimat. Oleh sebab itu, mahasiswa memilih masuk prodi bahasa Arab. Menurut mahasiswa, bahasa arab adalah bahasa yang, unik dan berbeda dengan bahasa lainnya.

Selain itu, beberapa peserta mahasiswa Unversitas Djuanda Bogor dalam persepsinya mengenai pemilihan prodi bahasa Arab, adalah sebagai berikut.

Ya, bagi saya (Latifurrohim: 21) masuk ke prodi bahasa Arab, atau belajar bahasa Arab, adalah sebuah keharusan. Kenapa? Karena dengan belajar bahasa arab berarti saya juga sedang belajar berbicara, membaca, menulis, membuat, dan memahami makna suatu kalimat atau lafaz, baik kalimat yang ada dalam Al-Qur'an, Hadis, dan Kitab Ulama. Seperti dikatan dalam bait kitab imrithi:

$$
\text { والنحو اولى أولا أن بعلم إذ الكلام دونه لا بفهم }
$$

Inti dari bait tersebut adalah: "Bahwasanya ilmu nahwu (ilmu yang mempelajari kalimat bahasa Arab) itu lebih diutamakan pembelajarannya, karena perkataan pun tak akan bisa dipahami tanpa ilmu nahwu tersebut. Dengan alasan tersebut, sudah membuat saya yakin bahwa untuk memilih prodi dan pembelajaran bahasa Arab, adalah paling tepat untuk saya.

Menurut saya (Mujib: 20) masuk prodi bahasa Arab adalah suatu kebanggaan tersendiri karena bisa belajar bahasa asing, tentunya saya memang senang belajar bahasa Arab sejak di bangku SD (Sekolah Dasar). Karena dengan belajar bahasa Arab otomatis kita pun sedang belajar Al-Qur'an, sehingga kita dapat memahami keduanya.

Ya, awalnya saya (Putri: 20) memilih prodi bahasa Arab karena, adanya dorongan dari orang tua. Alasannya, karena takut tidak bisa mengikuti pembelajaran tersebut tapi, ketika saya sudah masuk ke prodi bahasa Arab, alhamdulillah ternyata saya bisa mengikuti pembelajaran itu dan memang saya ada 
Persepsi Mahasiswa dalam Pemilihan Prodi Bahasa Arab

basicnya disana. Jadi, saya sangat bersyukur bisa masuk ke prodi tersebut dengan pembelajaran yang menyenangkan menurut saya.

Dari persepsi ketiga di atas, dapat dikatakan bahwa yang masuk prodi bahasa Arab, rata-rata memang menyukai pembelajaran bahasa Arab. Menurut mahasiswa bahwa masuk prodi bahasa Arab, merupakan kebanggaan untuk mereka. Karena, di dalam pembelajarannya terdapat suatu pembelajaran yang berbeda dengan yang lainnya. Sehingga, mahasiswa sangat senang untuk masuk ke prodi bahasa Arab.

\section{Faktor-faktor Mahasiswa dalam Memi- lih Prodi Bahasa Arab}

Setiap mahasiswa di pengaruhi oleh faktor-faktor yang mendorongnya dalam memutuskan pemilihan prodi saat belajar di perguruan tinggi, meski begitu setiap orang memiliki pertimbangan yang berbeda dan faktor dominan yang mempengaruhi dalam pengambilan keputusan tersebut. Hal ini dialami oleh sebagian besar mahasiswa tingkat pertama di perguruan tinggi termasuk jurusan pendidikan bahasa Arab.

Dalam menentukan pilihan setiap orang pasti dipengaruhi oleh berbagai faktor, terlebih lagi jika pilihan tersebut berkaitan dengan masa depan, salah satunya menentukan prodi. Menentukan prodi yang akan dipilih pada tingkat perguruan tinggi pada dasarnya termasuk pada perencanaan karier. Hal ini tentu saja menjadi penting, terlebih bagi calon mahasiswa yang hendak atau sedang menempuh pendidikan di perguruan tinggi, khususnya di Universitas Djuanda Bogor.

Selanjutnya beberapa faktor yang mempengaruhi mahasiswa dalam memilih prodi bahasa Arab, di antaranya: 1) Orang tua: Echols (418) mengemukakan bahwa parent yang memiliki arti 1) Orang tua, 2) Ayah, dan 3) Ibu.

Orang tua adalah komponen keluarga yang terdiri dari ayah dan ibu, dan merupakan hasil dari sebuah ikatan perkawinan yang sah yang dapat membentuk sebuah keluarga. Orang tua memiliki tanggung jawab untuk mendidik, mengasuh, dan membimbing anakanaknya untuk mencapai tahapan tertentu yang menghantarkan anak untuk siap dalam kehidupan bermasyarakat.

Terkait pengaruh orang tua dalam memilih prodi bahasa Arab, yakni kondisi sosial ekonomi keluarga, secara tidak langsung keberhasilan orang tuanya merupakan "beban" bagi anak se- 
hingga dalam menentukan pilihan pendidikan tersirat untuk ikut mempertahankan kedudukan orang tuanya. 2) Teman-teman kelompok sebaya: Robert (2005) mengemukakan bahwa teman sebaya adalah anak-anak dengan usia atau tingkat kedewasaan yang kurang lebih sama. Tidak dipungkiri, kenyataannya lingkungan pergaulan dalam kelompok remaja cukup memberi pengaruh pada diri seorang individu dalam memilih prodi di perguruan tinggi.

Sunarto (1996) mengemukakan bahwa lingkungan merupakan faktor yang mempengaruhi seseorang dalam menjalani pilihan hidup tidak hanya di dalam dirinya saja, ketika pilihan internal mahasiswa menginginkan menjadi guru dan lingkungan baik keluarga, teman sebaya, sekolah dan masyarakat mendukung maka timbul kepercayaan diri mahasiswa tersebut dalam menempuh pendidikan karena merasa bahwa pilihannya bukanlah pilihan yang salah dengan itu menjadi dasar baginya untuk berprestasi lebih baik lagi untuk menunjukkan bahwa apa yang dia yakini serta apa yang telah lingkungan dukung untuknya adalah sebuah pilihan tepat.

Kami merekrut 38 peserta mahasiswa yaitu (11 laki-laki dan 27 perem- puan), di antara 38 peserta mahasiswa ini berusia antara (20-23 tahun). Mahasiswa tersebut mempunyai persepsi yang berbeda dalam menjawab soal pertanyaan yang sudah dibuat oleh penulis. Pada umumnya persepsi mereka masuk prodi bahasa arab, yaitu adanya keinginan dari diri sendiri dan adanya dorongan dari kedua orang tua.

\section{SIMPULAN}

Secara umum mahasiswa sudah menunjukkan persepsi yang positif serta kesadaran akan pentingnya bahasa arab dalam kehidupan sehari-hari, baik sebagai muslim yang belajar dengan motivasi agama maupun sebagai mahasiswa yang sedang menghadapi tantangan global terkini. Mereka pun merasakan adanya keuntungan berupa pengetahuan dan nilai tambah serta manfaat konkret dari kemampuan bahasa Arab meski hanya tingkat dasar.

Manfaat itu pun didasari, bahwa manfaat tersebut dapat digunakan sebagai modal tambahan untuk memasuki dunia kerja. Mengingat pentingnya bahasa Arab, mereka pun mengusulkan agar mata kuliah bahasa Arab tetap ada sebagai ciri khas UAI dan mendapatkan dukungan kebijakan dan fasilitas yang 
memadai agar motivasi belajar mahasiswa terjaga.

Persepsi mahasiswa tentang prodi bahasa Arab cukup positif. Itu ditandai dengan persepsi mereka bahwa secara umum mahasiswa memilih pendidikan prodi bahasa arab. Mereka beralasan bahwa masuk prodi bahasa Arab adalah suatu kebanggaan yang memang pembelajaran yang mereka senangi. Sehingga, mereka lebih memilih prodi bahasa Arab. Menurut persepsi mahasiswa, belajar bahasa arab adalah pembelajaran yang unik di mana di dalam pembelajarannya terdapat pengetahuan, yang berkaitan dengan keagamaan serta pem-belajaran yang berbeda dengan yang lainnya. Oleh sebab itu, mereka memilih prodi bahasa Arab.

\section{DAFTAR PUSTAKA}

Ahnan, Maftuh. (1999). Metode Belajar Ilmu Sharaf. Surabaya: Terbit Terang.

Bonwell, C.C. (1995). Active Learning: Creating excitement in the classroom. Center for.

Dahlan, Ahmad.Z. (2012). Syarah alJurumiyyah. Surabaya: Beirut: Dar al-Khotob al-Alamiyyah.

Dunette. (1976). Keterampilan pembukuan. Jakarta: PT. Grapindo Persada.
Davis, Gordon. B. (1994). Management System Information. Jakarta: Midas Surya Grafindo.

Echols, Hasan. (2010). Kamus Inggris Indonesia. Jakarta: PT. Gramedia Pustaka Utama.

Ghalayain, Mustafa. (2009). Jami alDurus al-Arabiyyah. Surabaya: Beirut Dar al-Khotob al-Alamiyyah.

Lester, Crow. \& Crow Alice. (1984). Psikologi Pendidikan. Surabaya: Bina Ilmu.

Musbikin, Imam. (2012). Mengatasi Anak Mogok Sekolah dan Malas Belajar. Jogjakarta: Laksana.

Mulyana, Deddy. (2005). Ilmu Komunikasi: Suatu Pengantar. Bandung: Remaja Rodaskarya.

Nadler. (1986). Keterampilan dan Jenisnya. Jakarta: PT. Grapindo Persada.

Robert, Baron. (2005). Psikologi Sosial. Jakarta: Erlangga.

Walgito, Bimo. (2004). Psikologi Sosial. Yogyakarta: Andi Offest.

Winardi, J. (2002). Motivasi dan Pemotivasian dalam Manajemen. Jakarta: PT. Raja Grafindo

Robbins, S.P. (2004. Perilaku Organisasi. Jakarta: Salemba Empat.

Soegeng, A.Y. (2012). Pengembangan Sistem Pembelajaran. Semarang: IKIP PGRI Semarang Press.

Sunarto, Agung. H. (2008). Perkembangan Peserta Didik. Jakarta: PT. Rineka Cipta. 
Thoimah, Rosydi. A. (1994). Metode Pembelajaran Bahasa Arab. Kairo: Darul Fikri Al'Arab.

Thomas, J. (1972). The variation of memory with time for information appearing during alecture. Studies in. 